\title{
Plants of the prairie
} aquatic ecosystems

\section{1*I Agriculture JuN Canada 1991}

Library / Bibliothèque, Ottawa K1A 0C5

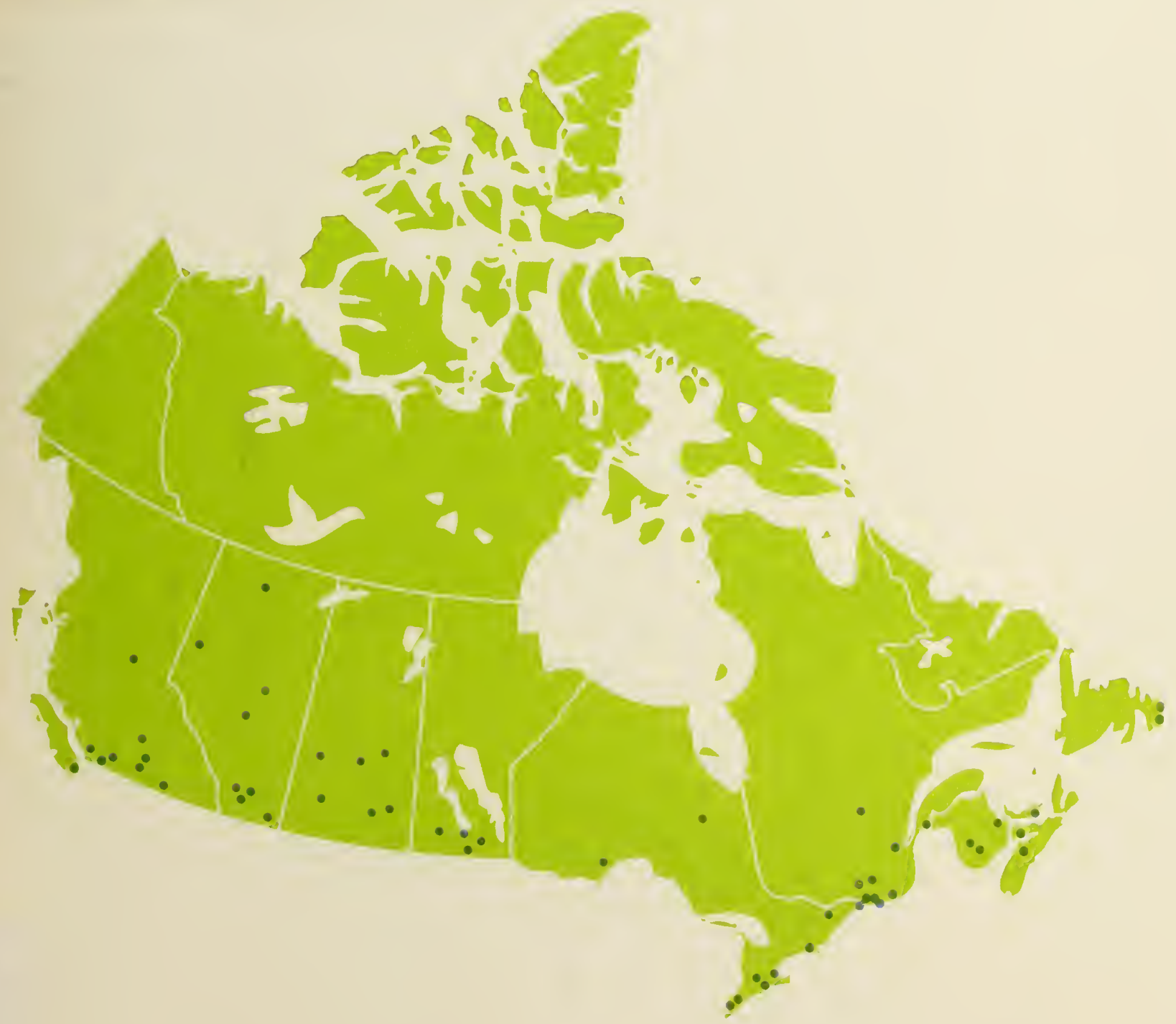


Digitized by the Internet Archive in 2013 


\section{Plants of the prairie aquatic ecosystems}

JOHN R. ALLAN and JAMES A. BRAGLIN-MARSH

Research Station

Lethbridge, Alberta

Technical Bulletin 1991-9E

Lethbridge Research Station Contribution No. 15

Research Branch

Agriculture Canada

1991 
Copies of this publication are available from

Dr. J.R. Allan

Soil Science Section

Research Station

Research Branch, Agriculture Canada

P.O. Box 3000, Main

Lethbridge, Alberta

T1J 4B1

Produced by Research Program Service

( Minister of Supply and Services Canada 1991

Cat. No. A54-8/1991-9E

ISBN 0-662-18839-X 
CONTENTS

SUMMARY/RESUME ............................ ii

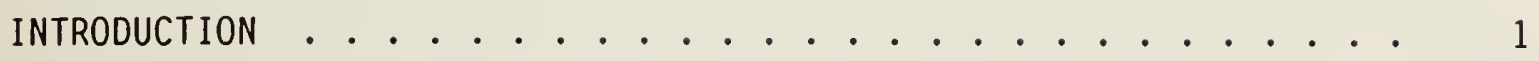

\section{SPECIES DESCRIPTION}

Group I. Submergent aquatic plants ........... 8

Group II. Floating-leaved aquatic plants . . . . . . . 17

Group III. Free-floating aquatic plants . . . . . . . 21

Group IV. Emergent aquatic plants ........... 23

SELECTED REFERENCES .................... 31 


\section{SUMMARY}

Native and introduced aquatic plants have been surveyed in southern Alberta and Saskatchewan since 1966. The generally accepted belief is that diversity in plant species increases as one moves south toward the tropics (equator). However, the wide range of aquatic environments, natural and man-made, has created favorable habitats for many submergent, floating-leaved, free-floating and emergent aquatic plants. This publication lists the taxa of the aquatic vascular plants found in Prairie aquatic ecosystems, provides a description of the common and less common species and one or more characteristics of the dominant species found in the various natural and man-made environments.

\section{RÉSUMÉ}

Les plantes aquatiques indigènes et introduites font l'objet d'un relevé dans le sud de 1'Alberta et de la Saskatchewan depuis 1966. Il est généralement accepté que la diversité des espèces végétales s'accroît au fur et à mesure que $l^{\prime}$ on avance vers le sud et s'approche des Tropiques (équateur).

Toutefois, la gamme étendue de milieux aquatiques, naturels et artificiels, a créé des habitats favorables à de nombreuses plantes aquatiques immergées, flottantes enracinées et non enracinées et émergentes. Cette publication présente une liste des taxons des plantes vasculaires aquatiques que l'on retrouve dans les écosystèmes aquatiques des Prairies, une description des espèces courantes et moins communes ainsi qu'au moins une caractéristique de l'espèce dominante dans les divers milieux naturels et artificiels. 


\section{INTRODUCTION}

Through the ages vascular plants have spread over the land, adapting themselves to the mechanical and physiological rigors of terrestrial life. They escaped from aquatic environments and developed the seed-producing habit. The most successful plants no longer needed water as a medium for ovule fertilization and spread rapidly over the land surface to replace the gymnosperms as the dominant vegetation. Yet, despite this triumphant occupation of the land, a few angiosperms returned to the aquatic environment of lakes and rivers; some even returned to the sea. Here they live and reproduce in a partly or wholly submerged state. A liberal estimate of the number of plants in this specialized minority is unlikely to exceed $1 \%$ of the angiosperms and $2 \%$ of the pteridophytes. These vascular hydrophytes comprise 33 families, of which 30 have fewer than 10 genera each, 17 families are monogeneric, and 3 families are monotypic. This minority embraced the change to aquatic life so thoroughly that some had their leafy shoots completely submerged in water. Some ceased to take root in the substratum and spent their entire vegetative life floating freely in the water. But most of these vascular hydrophytes have retained the advanced reproductive methods of their terrestrial ancestors. Regardless of how deeply these plants grow underwater, most aquatic plants still strive to push their flowers to the surface of the water for pollination by insects or the wind.

The close relationship between the aquatic vascular plants and the aquatic environment is of prime importance to these plants and to other smaller plants and animals that depend on them for support, protection and food. Aquatic vascular plants are only a small part of the larger and more complex aquatic ecosystem, which can be regarded as the product of an interaction between the environment (the physical and chemical factors) and the plant community (the living component). This dynamic interaction involves the flow of energy through the aquatic system and a series of nutrient cycles. The trophic nature and biological productivity of the aquatic ecosystem in turn are the result of the specific geographical location and the human, geological, topographic and climatic factors acting on the ecosystems.

Currently on the Canadian prairies there are 630,000 ha of land under irrigation: 506,000 ha in Alberta, 100,000 ha in Saskatchewan, and 24,000 ha in Manitoba. Excessive growth of rooted, submerged, aquatic macrophytes is a serious problem in Prairie irrigation systems. In Alberta, more than $12,500 \mathrm{~km}$ of primary, secondary and on-farm irrigation and drainage canals are infested with nuisance algae and aquatic weeds. Water is delivered to Alberta land through an irrigation distribution system in which $90 \%$ of the canal system is earth-lined. Scattered throughout the system are numerous on-stream irrigation storage reservoirs. Aquatic macrophyte growth in southern Alberta canals can impede the flow of irrigation water by as much as $91 \%$ of design capacity by mid-August. The entire system is a prime habitat for the excessive growth of numerous aquatic plant species.

Field surveys over the last 20 years at the Lethbridge Research Station have identified a number of aquatic plant infestation characteristics, which has enabled the effective implementation of an integrated aquatic vegetation management program. 
Previous studies have shown that the carrying capacity of the irrigation canal, the velocity of the moving water, and the water chemistry such as the total solids, dissolved total solids, and silt content of the irrigation canal generally determine the aquatic weed species growing in the canal (Table 1). The reduced day-length (photoperiod) available to rooted, submerged, aquatic macrophytes is related to the north-south or east-west orientation of a canal. Preliminary studies on radiant energy indicate that the reflection and penetration of radiant energy by the water in the canal may influence the occurrence of native aquatic plant species such as northern and green water milfoil plants (Myriophyllum spp.). Previous studies with aquatic herbicides applied at different times during the aquatic weed-growing season have demonstrated a marked difference in effectiveness and plant susceptibility. This was thought to be due to changes in water temperature, water chemistry, silt loading, and degree of vegetative plant development. However, studies during the summer of 1989 documented the naturally occurring seasonal appearance and changes in growth habit of various native aquatic plant species during the irrigation season. This new information will help establish better criteria for the selection of effective chemical and biological aquatic plant management techniques.

Aquatic vascular plants may be described by several convenient technical terms. Aquatic habitats cannot always be sharply distinguished from terrestrial ones. In most climates the seasonal fluctuation of the water table means that in the spring and fall there may be standing water, which dries out in summer. Also, there is often no abrupt change from land to water, but rather a gradual transition from dry to waterlogged to submerged soils. In this publication, a 'vascular hydrophyte' is defined as a plant growing in water, in soil covered with water, or in soil that is usually saturated with water. The different life forms of vascular hydrophytes can then be divided into four general categories (from Sculthorpe, 1967): submergent (Fig. 1), floating-leaved (Fig. 2), free-floating (Fig. 3), and emergent (Fig. 4) aquatic plants. This classification is intended to provide a guide for the identification of vascular hydrophytes found in Western Canada.

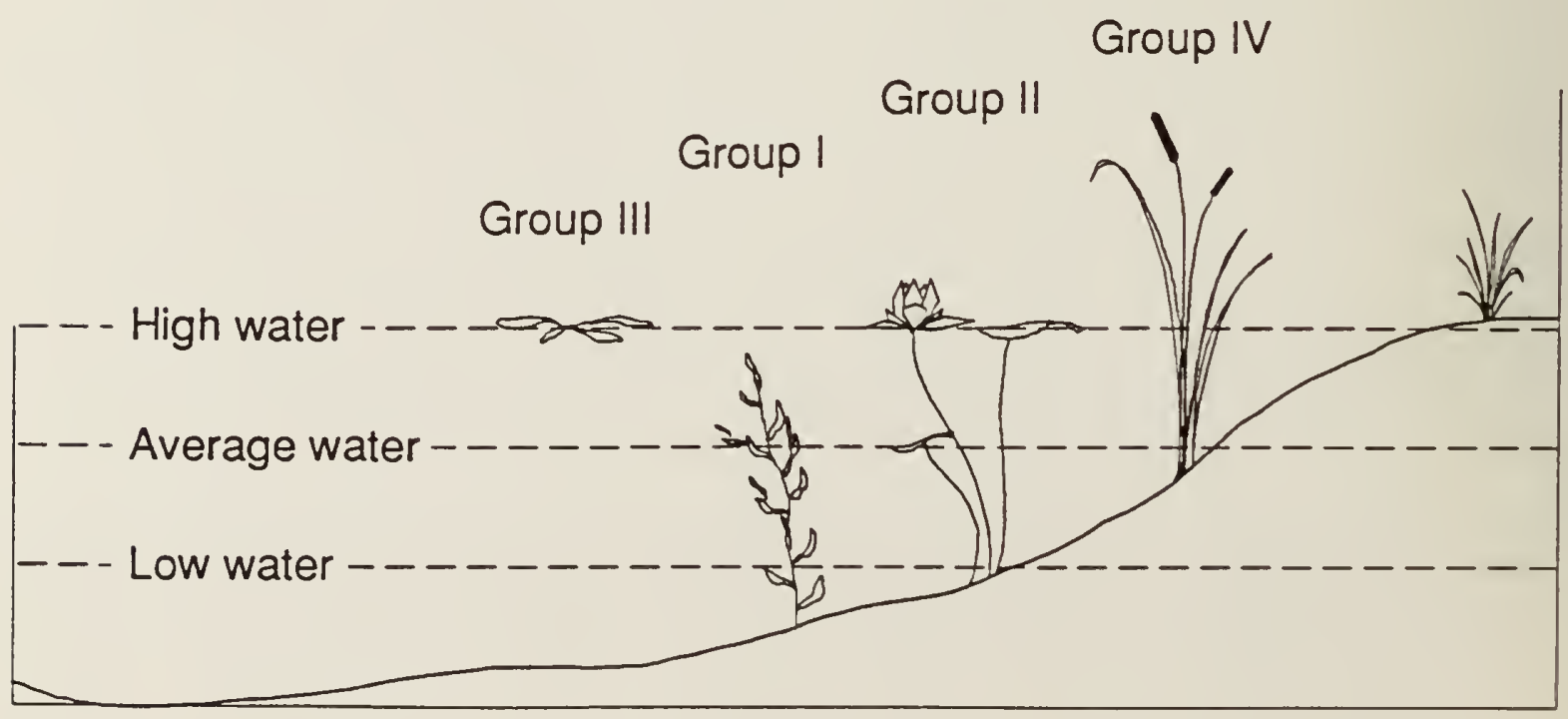


Table 1. Rooted, submerged, aquatic macrophytes occurring in southern Alberta irrigation canals.

\begin{tabular}{lccc}
\hline & \multicolumn{4}{c}{ Canal flow rate $\left(\mathrm{m}^{3} / \mathrm{s}\right)$} \\
\cline { 2 - 3 } Species & $\begin{array}{ccc}1.5-10.0 \\
(50-350 \mathrm{cfs})\end{array}$ & $(350-1000 \mathrm{cfs})$ & $(>1000 \mathrm{cfs})$ \\
\hline
\end{tabular}

Ranunculus trichophyllus

(water crowfoot)

$x$

Chara vulgarus

(stonewort or muskgrass)

Zannichellia palustris

(horned pondweed)

Potamogeton friesii

(Fries' pondweed)

Potamogeton foliosus

(Teafy pondweed)

Potamogeton strictifolius

(straight-leaf pondweed)

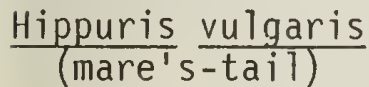

Myriophyllum heterophyllum $\quad x$

(variable leaf milfoil)

Myriophyl lum exalbescens

(common or northern water milfoil)

Myriophyllum verticillatum

(green water milfoil)

Potamogeton pusillus

(small-Teaf pondweed)

Alisma gramineum

(narrowleaf water plantain)

Potamogeton richardsoni i

(Richardson's pondweed)

Potamogeton pectinatus

(sago pondweed)

Potamogeton zosteriformis

(flat-stemmed pondweed)

Potamogeton vaginatus

(giant or sheathed pondweed) $x$

$x$

$x$

$x$

$x$

$x$

$x$

$x$

$x$

$x$

$x$

X

$x$

X

$x$

X

X

X 


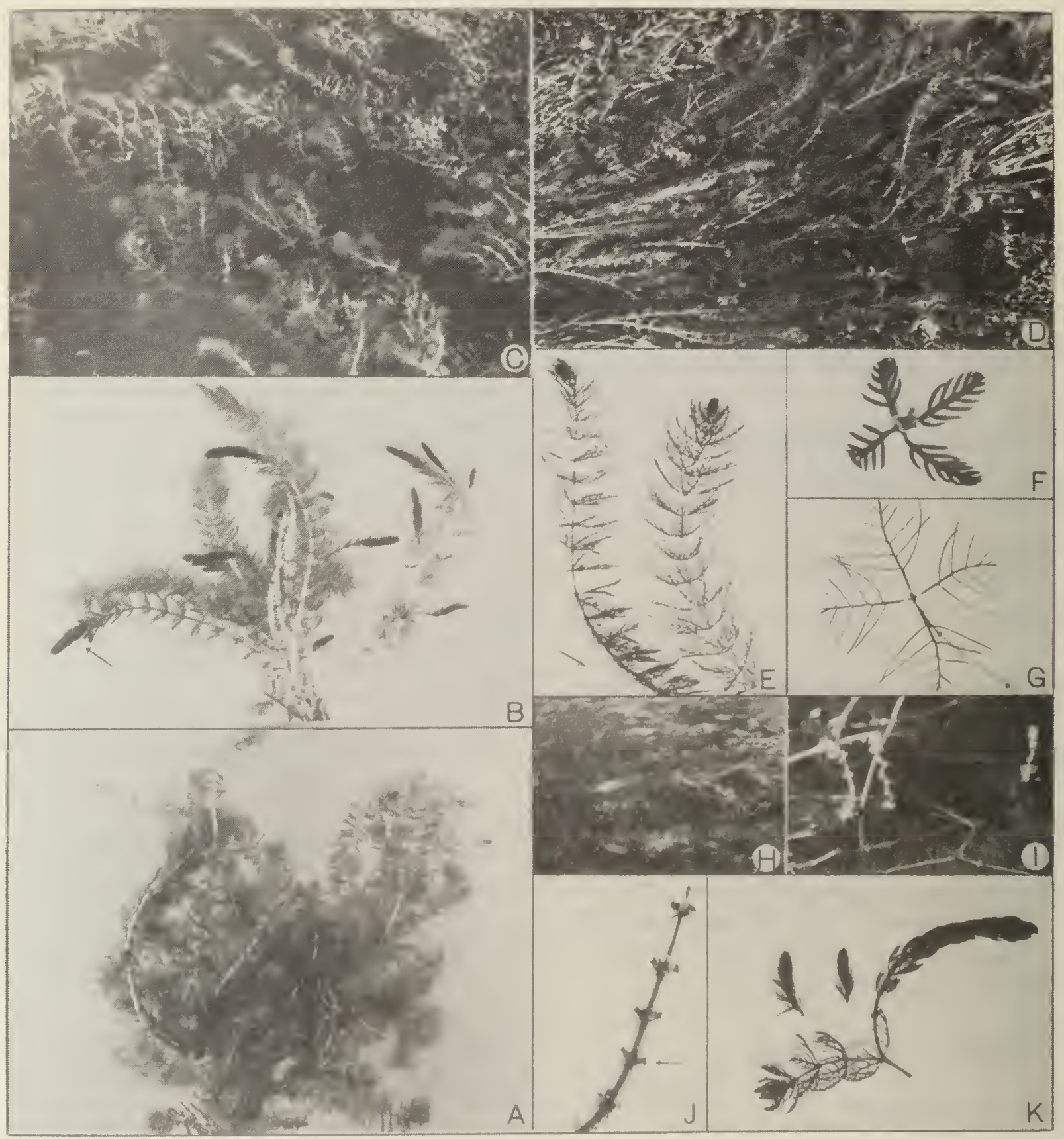

Figure 1. Life cycle of the submergent rooted aquatic macrophyte, Myriophyllum verticillatum. A. Vegetative shoot of water milfoil. B. Mature $p l a n t$ of water milfoil showing the production of overwintering buds or turions at the tip of each vegetative branch. $C$. Appearance of the plant in flowing water. D. Appearance of the plant in standing water with other rooted aquatic plant species. E. Stem fragments showing root development at the base of the shoot. F. Leaf structure of overwintering turion. G. Typical leaf structure of water milfoil plant. H. Flower head at the surface of the water. I. Flower head extending into the air for wind pollination. J. Details of flower head showing characteristic flower bracts used to identify Myriophyllum spp. K. Details of Myriophyllum spp. turions. 


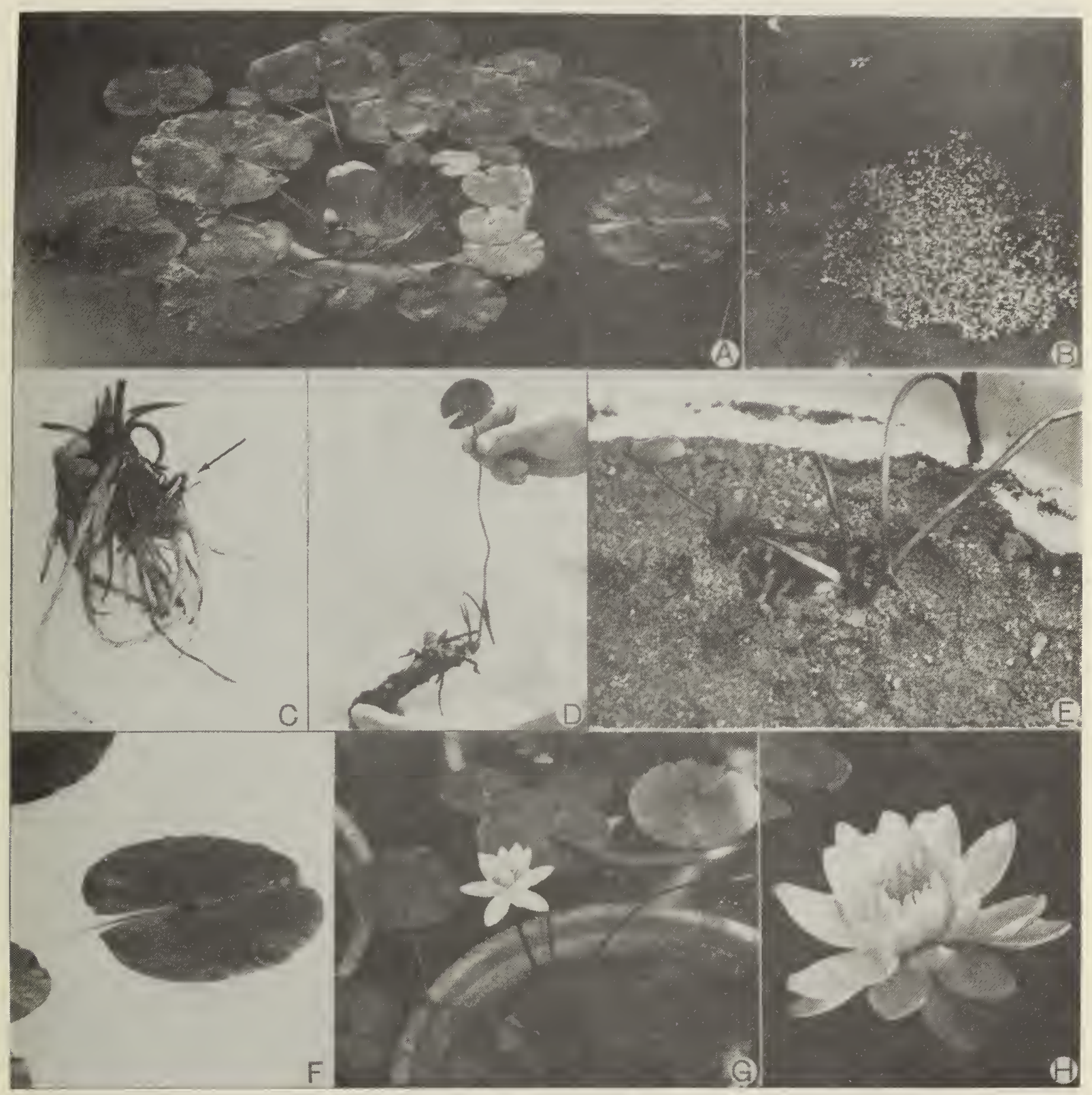

Figure 2. Life cycle of the floating-leaved aquatic macrophyte, Nymphaea odorata. A. The typical plant growing under greenhouse or ornamental water garden conditions. B. Aerial view of water lilies growing in lakes in northern Alberta. C. Crown of water lily plant showing vegetative shoots. D. Tuber of water lily plant showing extended leaf petiole. E. Water lily planted in tub in an ornamental water garden. F. Detail of floating leaf of water lily plant. G. Water lily plant with fully open flower. H. Detail of the opened water lily flower. 

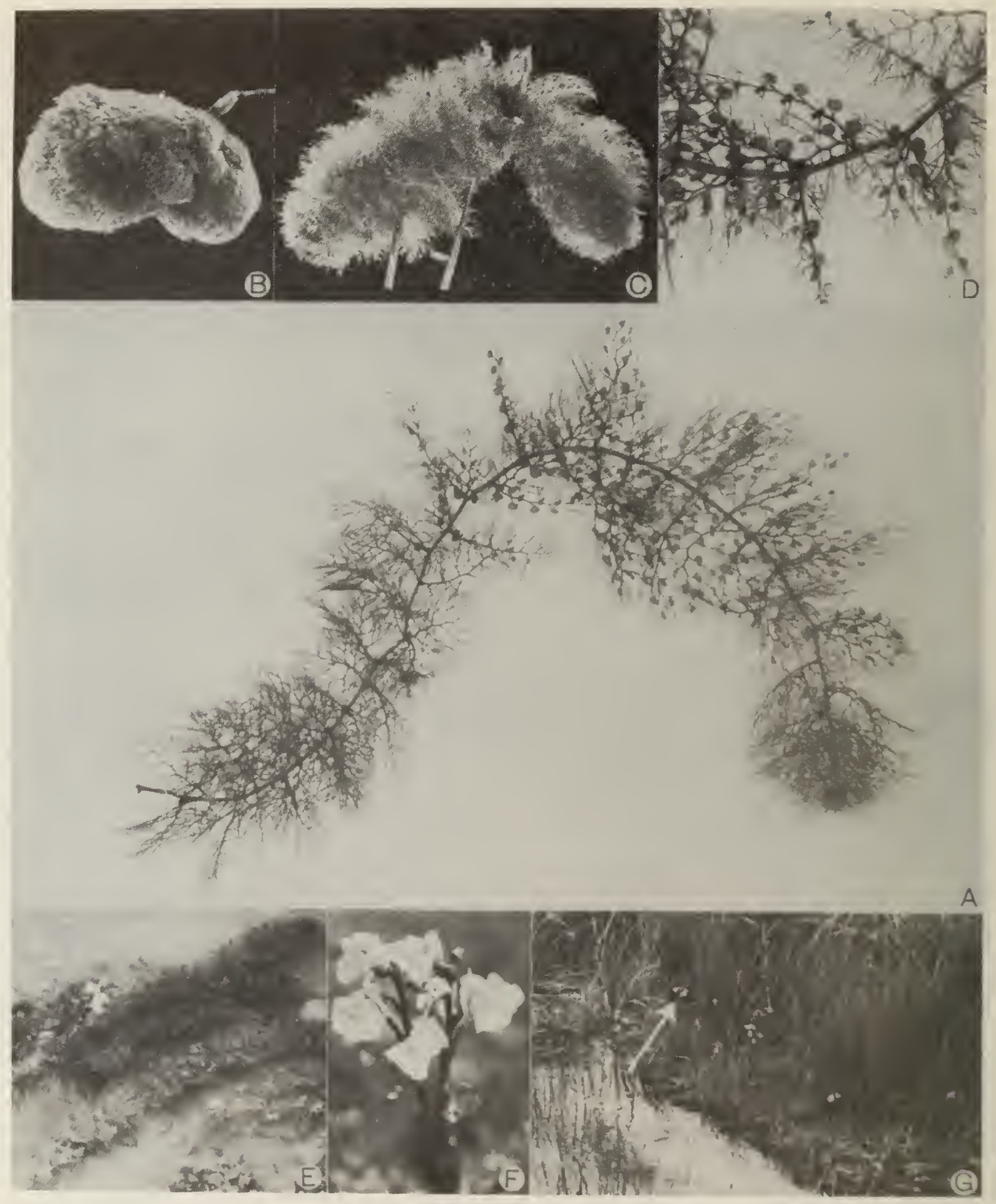

Figure 3. Life cycle of the free-floating aquatic macrophyte, Utricularia vulgaris. A. Vegetative shoot completely lacking roots but possessing small black bladders that assist in the trapping of aquatic organisms for food. B. Overwintering turion of the common bladderwort. C. The expansion of the turion in the spring when water temperature reaches $15^{\circ} \mathrm{C}$. D. Details of leaf structure showing the small bladders. E. The freefloating bladderwort along the shore of a stock-watering pond showing the showy flower. F. Details of the flower head. G. Typical habitat of the common bladderwort showing the numerous flower heads. 


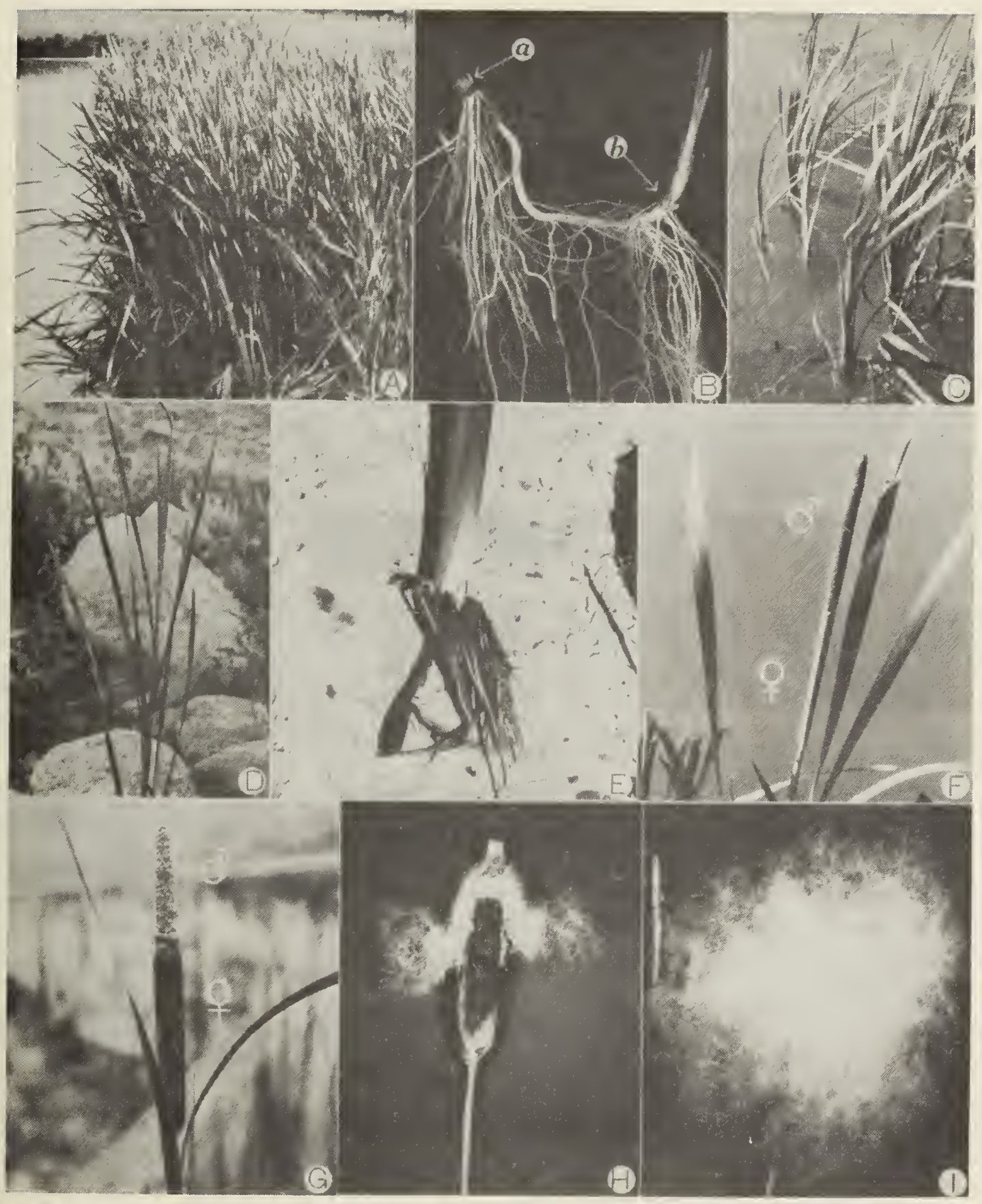

Figure 4. Life cycle of the emergent aquatic macrophyte, Typha latifolia. A. Colony of cattails growing at the edge of a pond. B. Underground rhizome system showing two vegetative shoots and the root system. C. Young cattail shoots in 10-20 cm of water. D. Mature plant showing leaf formation and structure. E. Crown of a mature plant with root system. F. Early inflorescence stage or 'window' when plants are most susceptible to chemical control showing male flowers above the female flowers.

G. Young flower head with developing female portion and the male portion above after the pollen is shed. H. Mature cattail head just beginning to shed the wind-disseminated seeds. I. Exploded cattail seed head with winged seeds ready to be wind-blown to potential marsh sites. 


\section{SPECIES DESCRIPTION}

Group I. Submergent aquatic plants

A. Plants with feather-like, limp leaves on flexible underwater stems. Stem tips often extend above the surface of the water.

1. northern water milfoil Myriophyllum exalbescens Fern.

Range: British Columbia to Manitoba. Usually in calcareous still water, very slow streams, ponds, pools, and lakes.

Plant: $\quad$ Perennial, submerged, with smooth, simple stems. Reddish-purple when fresh, turn white when dry.

Leaves: $\quad$ Finely dissected into 6-10 pairs, $1-3 \mathrm{~cm}$ long; 3-5 segments arranged in whorls around the stem.

Flower spike: Three, arranged around the stem with upper flowers male and lower flowers female. Leaf-like bracts shorter than the flowers.

2. green water milfoil Myriophyllum verticillatum L.

Range: British Columbia to Manitoba. In shallow water with high clay and calcium content.

Plant: $\quad$ Similar to northern water milfoil.

Leaves: $\quad$ Finely dissected into 9-15 pairs, 1-4 cm long; 4-5 segments arranged in whorls around the stem.

Flower spike: Three in number, arranged around the stem. Bracts deeply divided and much longer than the flowers.

B. Plants with needle-like to oval, paired, or bunched leaves on flexible underwater stems.

1. mare's-tail Hippuris vulgaris $L$.

Range: British Columbia to Manitoba. In shallow pools and along margins of lakes, streams, and ponds. 
Plant:

Leaves:

Flowers:

2. water starwort

Range :

Plant:

Leaves:

Flowers:

3. horned pondweed

Range:

Plant:

Leaves:

Seed:

Perennial, upright, and at least partly out of the water. Stems erect, hollow, rarely forked, smooth, and cylindrical arising from creeping rhizome.

Two types: submerged ones delicate, linear, 2-4 cm long, slender, narrowing to a top in whorls of six or more. Aerial leaves much shorter, 0.5-1.0 cm long, thicker, and firmer than submerged ones.

Appear in axils of upper aerial leaves.

\section{Callitriche palustris L.}

British Columbia to Manitoba. In shallow quiet ponds and lakes with high calcium content.

Low perennial growing submerged or partly floating along muddy shores in clear water.

Lower submerged leaves pale green without a petiole, linear, 10-15 $\mathrm{mm}$ long, 1-nerved. Transitional

leaves lance-shaped below water surface and spatulate above. Floating leaves petioled, shaped like a spatula, 5-10 long, crowded at stem tip. Have paired bracts in axils of upper leaves.

\section{Zannichellia palustris L.}

British Columbia to Manitoba. In ponds, ditches, or very slow-moving streams.

Submerged, with slender, hair-like, branched stems.

Submerged, long, needle-like but flat, 2-10 cm long and $0.2-0.5 \mathrm{~mm}$ wide, whorled with 1 nerve with a sharp tip at the apex.

Curved, often with teeth directed outward on a short stalk. Prominent beak opposite the stalk.

4. Canada waterweed Elodea canadensis (Michx.) Planchon

Range:

British Columbia to Manitoba. In quiet lakes and ponds with high calcium content.

Plant:

Submerged, freely branching, forming large masses in the water. Stems slender with numerous whorls of leaves and often rooting at the nodes. Root system very fibrous. 
Leaves:

Flower:
Whorled, without petioles, linear, 1.2-4 $\mathrm{mm}$ wide, usually minutely toothed with 1 nerve.

Male and female flowers borne on separate plants (dioecious) with flowers falling away rapidly. Male flowers in long stalks.

\section{5. marsh-purslane Ludwigia palustris (L.) Ell. var. americana}
Range:
Leaves:
British Columbia to Manitoba. Usually on muddy banks or pond edges.
Plant:
Has creeping, slender stems sprawling on wet ground or partly underwater. Occasionally in clear springs or spring-fed streams.
Flower: diamond shape with a slender petiole.
Very smal1, without petioles, on short stalks in the leaf axils.
Submerged leaves opposite, up to $6 \mathrm{~cm}$ long, thin,

C. Plants with clustered branches on fine-forked, bladderless, usually limp leaves on flexible underwater stems.

1. muskgrass Chara sp.

Range: British Columbia to Manitoba.

Plant: $\quad$ A non-vascular plant belonging to the algae family. The plant is very rough, harsh, generally encrusted with lime $\left(\mathrm{CaCO}_{3}\right)$, varying with the degree of water hardness in which it grows. Each joint of the stem consists of a single cell. Whorled branches appear at nodes, which appear to be leaf-like. Oogonium containing fertilized egg cell appears as a bright orange structure in the axils of the stem-like branches. Fresh plants have strong fishy smell.

2. white water buttercup Ranunculus circinatus var. subrigidus

Range: British Columbia to Manitoba. In ponds, ditches, streams, and pools.

Plant: Perennial, submerged with smooth, elongated, branched stems rooting at the lower nodes. 
Leaves:

Submerged, 1.0-2.5 cm long, finely dissected into thread-like division with distinct clasping petiole sheath at the base.

Flower:

Solitary with five broad, conspicuous, white petals, each with a nectariferous spot or pit at the base of the petal.

3. yellow water buttercup Ranunculus purshij Rich.

Range: British Columbia to Manitoba. In shallow lakes, along stream borders and on mud marsh flats.

Plant: Perennial, submergent or inhabiting wet marshy ground. Stems smooth, trailing roots at the lower nodes.

Leaves: $\quad$ Submergent leaves delicate, circular or kidneyshaped in outline, 3-5 cleft into wedge-shaped divisions. Emergent or floating leaves smaller, thicker with wider lobes. Both types on petioles.

Flower: $\quad$ Solitary with five circular yellow petals with a nectariferous spot at base.

4. coontail Ceratophyllum demersum $L$.

Range:

British Columbia to Manitoba. Widespread.

Plant:

Submerged, herbaceous with freely branching stems having leaves crowded at the tips ("coontail" effect). Plants often form large dense masses.

Leaves:

Finely divided, rigid or somewhat brittle leaves are cut into 2-4 forked divisions and are produced in whorls at stem nodes. Individual divisions have tooth-like projections along one side.

5. water marigold Megalodonta beckij (Torr.) Greene

Range:

Saskatchewan to Manitoba. In ponds and slowly moving water.

Plant:

Submergent.

Leaves:

Submergent leaves finely dissected into thread-like segments appearing whorled and crowded at the upper nodes. Very soft appearance but firm in texture, simple, without petioles. Margins have sharp teeth directed forward. 


\section{Flower:}

Aggregation of yellow flowers into heads extending above the surface of the water.

D. Plants with thread-like to ribbon-like leaves scattered singly on flexible underwater stems, often paired or bunched toward the stem tips. Underwater leaves collapse or partly collapse when taken out of water.

1. Fries' pondweed Potamogeton friesii Rupr.

Range: British Columbia to Manitoba. In relatively freshwater ponds and sloughs.

Plant: $\quad$ Arises from a winter bud with stems compressed; thread-like, simple branching produces numerous short branches or leaf-tuft which develop into winter buds in August to early September.

Leaves: Uniform, bright green and translucent, $2.5-8.5 \mathrm{~cm}$ long and 1.5-3.5 mm wide, with broad, blunt, or rounded leaf tip, 5-7 nerved with slender, single cell band of elongated lacunae or air space tissue on each side of midrib. Lateral nerves finer but distinct, joining midrib well below tip.

Winter buds: Terminal on short, lateral branches, narrowly fan-shaped, 1.2-2.5 cm long.

2. narrow-leaf pondweed Potamogeton strictifolius Benn.

Range :

British Columbia to Manitoba.

Plant:

Arises from a winter bud with compressed, threadlike stems, simple or sparsely and irregularly branched producing simple, more or less rigid branches in upper axils.

Leaves: $\quad$ Bright green, firm, often rolled backward from the margins, very narrowly linear, 2-7 cm long and $0.5-2.5 \mathrm{~cm}$ wide, rounded tip with short, small, abrupt, tooth-like tip, 3-nerved without air space tissue, lateral nerves indistinct, joined at midrib 1-2 $\mathrm{mm}$ below tip.

Winter buds: Terminal as well as axillary on short branches, fan-shaped, whitish and more or less fibrous. 
3. small-leaf pondweed Potamogeton pusillus L.

Range:

Plant:

Leaves:

Winter buds: Terminal, fan-shaped, 0.7-1.8 cm long, inner leaves

4. sago pondweed

Range:

Plant:

Leaves: covered by membranous stipules.

British Columbia to Manitoba. In fresh to mildly brackish water of sloughs, lakes, or slow-moving streams at depths of 0.3 to $1.5 \mathrm{~m}$.

Usually arises from winter buds without elongated rootstocks. Stems very slender and hair-like, freely branching with branches terminating in winter buds.

Linear to bristle-like, $1.0-8.5 \mathrm{~cm}$ long and 0.3-2.4 $\mathrm{mm}$ wide, 3-nerved with 3-5 bands of lacunae or air space tissue on either side of midrib, lateral nerve joins midrib 1-2 mm below tip.

\section{Potamogeton pectinatus L.}

British Columbia to Manitoba.

Submerged, stems slender, slightly reddish, many-branched with numerous leaves.

Narrowly linear, 3-15 cm long and 0.3-0.5 mm wide, bristle-like, more or less triangular in cross-section, tapering at the apex. No veins visible. Stipules fused to the base of the leaves for over half their length.

5. fine-leaf pondweed Potamogeton filiformis Pers.

Range:

Plant:

Leaves:
British Columbia to Manitoba.

Submerged, stems very short, repeatedly branched near the base in shallow water with branching reduced and stems elongated in deep water. Rhizomes creeping and white.

Linear to thread-like, rounded or blunt at the apex. Stipules united at base of leaves for $1 \mathrm{~cm}$.

6. giant pondweed

Range:

Plant: British Columbia to Manitoba.

Potamogeton vaginatus Turcz.

Submerged, stems very coarse and freely branching. 
Leaves:

Coarse, linear, 5-10 cm long and $1 \mathrm{~mm}$ wide, with blunt apex. Sheath very conspicuous and broader than stems.

7. flat-stemmed pondweed Potamogeton zosteriformis Fernald

Range:

Plant:

Leaves:
British Columbia to Manitoba.

Submerged with flattened, slightly winged stems several times wider than thick, many-branched.

Linear, 10-20 cm long and 2-5 mm wide, somewhat narrowed at the base with 1-3 prominent veins and 9-35 small secondary veins. Leaf apex rounded with a sharp point.

8. widgeon grass Ruppia maritima L.

Range:

British Columbia to Manitoba. In alkaline ponds, lakes, salt springs, and creeks.

Plant: $\quad$ Submerged with slender branching stems.

Leaves: Linear, 4-10 cm long and $0.5 \mathrm{~mm}$ wide, thread-like with blades up to $20 \mathrm{~cm}$ long, thick, 1-nerved with membranous sheaths at base.

Fruits: In an umbel-like cluster with each fruit on a separate pedicel.

E. Plants with lance-shaped or oval leaves scattered singly on flexible underwater stems, often paired or bunched toward the stem tips. Flowers are greenish-brown, occurring close together in oblong spikes.

1. variable-leaf pondweed Potamogeton gramineus $L$.

Range: British Columbia to Manitoba along the shores of lakes, ponds, and streams on muddy, drying shorelines.

Plant:

Many-branched with both submerged and floating leaves.

Leaves:

Form variable, depending on depth of submergence. Submergent leaves linear to lance-elliptic to oblanceolate in shallow water; $1-13 \mathrm{~cm}$ long and $0.1-1.5 \mathrm{~cm}$ wide; sessile with sharp-pointed tip. Floating leaves long petioled, ovate-elliptic, rounded at base, stipules persistent. 
Flowers: $\quad$ Spikes are compact, $1-2.5 \mathrm{~cm}$ long when present.

Reproduction: Once established, reproduces vegetatively by runners along the surface of the mud flat.

2. Richardson's pondweed Potamogeton richardsonii (Benn.) Rydb.

Range: British Columbia to Manitoba in lakes, rivers, streams, and irrigation canals and reservoirs. Generally in brackish or alkaline waters.

Plant:

Can grow in water up to $2 \mathrm{~m}$ deep with plants stretching to reach the water's surface. Prefers standing water or slow-moving streams and irrigation canals.

Leaves: All submerged, ovate to lanceolate with 7-33 prominent nerves with 3-7 very pronounced nerves. Leaves 1.5-10 cm long and 0.5-2 cm wide. Base of leaf clasps half to three-quarters the circumference of stem.

Flowers: $\quad$ Spikes are dense, $1.5-3 \mathrm{~cm}$ long with prolific seeds valued by water fowl.

Reproduction: Once established, reproduces prolifically by underground rhizomes. Rhizomes exist 6-10 cm under the surface of the mud and give rise to a new plant every $2-5 \mathrm{~cm}$.

3. white-stemmed pondweed Potamogeton praelongus Wulf.

Range: British Columbia to Manitoba in colder waters of lakes and streams.

Plant:

Grow in deep water, 2-3 m, with the white stems very pronounced when viewed from above.

Leaves:

All submerged, ovate to lance oblong, 0.5$30 \mathrm{~cm}$ long, 1-3 cm broad with 3-7 pronounced nerves. Base of leaf rounded and may clasp one-third the circumference of stem.

Flowers:

Spike has 6-12 whorls, $3-5 \mathrm{~cm}$ long. Seeds with prominent beak.

Reproduction: Vegetative reproduction occurs from stoutish rhizomes. Rhizomes covered with rusty spots and grow out in a circle from center point. 
4. curly-leaf pondweed Potamogeton crispus L.

Range: British Columbia to Alberta. In thermal heated discharges in Alberta. Prefers muddy, calcareous and brackish environments.

Plant: $\quad$ Very aggressive and once established will crowd out all other rooted, submerged aquatic plants. Stems flattened and very freely branching.

Leaves: Sessile, oblong to broadly linear, reddish, with sharply curved or curly leaf edges.

Flowers: $\quad$ Spikes very loosely flowered, up to $1.8 \mathrm{~cm}$ long with flattened seeds.

Winterbud: Winterbud or overwintering structure hardened and bur-like with short, hardened leaves. 
Group II. Floating-leaved aquatic plants

A. Plants with lance-shaped to round-floating leaves, which are notched at base. Leaves on flexible, upright to horizontal stems. Flowers white or yellow, showy.

1. spatterdock, yellow pond lily Nuphar luteum (L.) Sibth. \& Sm.

Range: $\quad$ British Columbia to Manitoba, widely scattered along pond margins and slowly moving streams

Plant: Leaves and flowers arise on long petioles and peduncles from underground rhizome.

Leaves: $\quad$ Long petioles flattened above with ridge running down midrib. Floating blades thick, dark green, $0.7-30 \mathrm{~cm}$ long and $0.5-25 \mathrm{~cm}$ broad. Ovate with broad-rounded basal lobes at petiole.

Flowers: $\quad$ Flowers are 2.5-4.5 cm high, 5-11 cm wide, deep yellow petals with purple at base of petal.

Reproduction: Very coarse rhizome, $2.5-7 \mathrm{~cm}$ thick with pronounced leaf scars.

2. white water lily, northern water lily Nymphaea tetragona Georgi

Range: $\quad$ Northern British Columbia, Alberta, Saskatchewan, and Manitoba.

Plant: $\quad$ Require still or dead water ponds and pools. This is the wild relative of the fragrant water lily used in water gardens.

Leaves: $\quad$ Arise on long petioles from underground rhizomes. Blades broadly ovate to obovate thin, 4-9 cm wide with a deep sinus at the base of the leaf.

Flowers: White, expanding in late afternoon, $2.5-4 \mathrm{~cm}$ wide.

Rhizome: $\quad$ Erect and unbranched.

3. northern arrowhead Sagittaria cuneata Sheldon

Range :

British Columbia to Manitoba. Generally along shorelines of lakes. Prefers calcareous or muddy shores. 
Plant:

Aquatic or marsh plant with milky juice. Plant height and leaf shape variable depending on submergence in water. Plants erect $(20-40 \mathrm{~cm}$ tall), simple and frequently branched.

Leaves:

Emergent leaf blades mostly arrow-shaped with basal lobes shorter than the terminal leaf part.

Flowers: $\quad$ Conspicuous, mostly unisexual with seeds, white petals. Fruiting heads are small balls, $0.8-1.0 \mathrm{~cm}$ in diameter.

Rhizomes: $\quad$ Slender, produce numerous tubers.

4. wapato, duck potato Sagittaria latifolia Willd.

Range: $\quad$ British Columbia to Manitoba. Along shorelines and sloughs and in slow-moving irrigation canals.

Plant: $\quad$ Perennial, erect, robust, $30-60 \mathrm{~cm}$ tall with milky juice.

Leaves: Leaf blades arrow-shaped with basal lobes equal to terminal leaf part.

Flowers: $\quad$ Petals showy white. Fruiting heads over $1.5 \mathrm{~cm}$ in diameter.

Rhizomes: $\quad$ Coarse, produce numerous tubers used as food by waterfowl.

5. fragrant water lily, white water lily Nymphaea odorata Ait.

Range: Northern British Columbia to northern Manitoba along lake shores and in marsh areas.

Plant: Widely used in water gardens.

Leaves: $\quad$ Arise along rhizome on long purplish-green to red petioles, blades nearly round, floating, thick and usually green above and purplish beneath, $0.5-25 \mathrm{~cm}$ in diameter.

Flowers: Very showy, white and fragrant, open in early morning.

Rhizomes: Horizontal, elongated, freely branched with leaf scars. 
B. Plants with lance-shaped to round floating leaves, which are tapered to slightly notched at the base. Some with thread-like to oval underwater leaves. Some with leaves partly growing out of water.

1. floating-leaf pondweed Potamogeton natans L.

Range: $\quad$ British Columbia to Manitoba in quiet lakes and streams.

Plant: $\quad$ Prefers still water in protected bays, stems simple and sparingly forked.

Leaves: $\quad$ Lacks underwater or submerged leaves. Floating

leaves well developed with petioles longer than

blades. Blades elliptic to ovate, thick and

lustrous, 4-9 cm long with rounded bàses.

Flowers: $\quad$ Spike is compact, 8-14 whorls, 3-5 cm long.

Reproduction: Vegetative reproduction from red-spotted underground rhizomes.

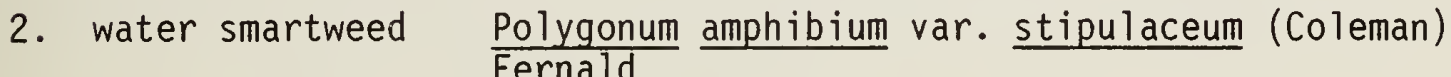

Range:

Plant:

Leaves:

Flowers:

Problem:
British Columbia to Manitoba in wooded swamps and along shores of streams, ditches, irrigation canals, and range dugouts.

Perennial with slender, tough, running rootstocks, generally aquatic but variable in habitat and leaf characters. May grow on exposed mud flats as water recedes.

Large, oblong to elliptic with long petioles floating on surface of water. Underwater stems trail.

Spike-like racemes are solitary or in pairs with bright scarlet to pink flowers, $1-3 \mathrm{~cm}$ long, $1.5 \mathrm{~cm}$ wide.

Plants trail out into water from shoreline, eventually plugging irrigation and drainage ditches. 
3. broad-leaf water plantain Alisma plantago-aquatica L.

Range: British Columbia to Manitoba on exposed mud flats.

Plant: $\quad$ Generally solitary on mud flats with only aerial leaves present.

Leaves: $\quad$ On long petiole, somewhat heart-shaped, $5-15 \mathrm{~cm}$ long with rounded base.

Flowers: Inflorescences are erect, $0.5-10 \mathrm{~cm}$ tall, with white flowers.

Seeds: $\quad$ Numerous and nut-like.

Value: $\quad$ Not a problem for irrigation systems and valuable as a wild bird food.

4. narrow-leaf water plantain Alisma gramineum Gmel.

Range: British Columbia to Manitoba in lakes, streams and irrigation canals and reservoirs.

Plant: $\quad$ Prefers calcareous to brackish water on muddy shores or in irrigation canals.

Leaves: $\quad$ Submerged leaves ribbon-like, up to $1 \mathrm{~m}$ long, bright green. Immersed leaves have slender petiole with firm, lanceolate to elliptic blades up to $10 \mathrm{~cm}$ long, $2 \mathrm{~cm}$ wide.

Flowers: $\quad$ On erect flowering stalks. with white to purplish flowers.

Seeds: $\quad$ Prolific seed producer.

Reproduction: Vegetative reproduction from stout corm-like base with fibrous roots. 
Group III. Free-floating aquatic plants

A. Plants with fine, forked, limp leaves mixed with small roundish bladders in flexible underwater stems. Flowers extend out of water.

1. common bladderwort Utricularia vulgaris L.

Range: $\quad$ British Columbia to Manitoba in deep, quiet ponds and pools.

Plant: $\quad$ Usually floats near the surface, has coarse submerged stems crowded with fine, dissected leaves.

Leaves:

Forked or pinnately dissected into coarse, hairlike segments. Numerous black bladders, 3-5 mm long, scattered among leaves.

Flowers: $\quad$ Six to 20 , produced on slender stalks along the edge of the ponds and pools. Bright yellow with brown markings.

Winterbuds: Buds are 1-2 cm long, of dense minute leaves crowded into a greenish-black hairy structure similar to elk droppings.

B. Plants small, free-floating, usually in shade of marsh plants. Reproduction is chiefly by offshoots from mature plants.

1. star duckweed

Range:

Plant:

Leaves:

Reproduction:

Overwintering:

\section{Lemna trisulca L.}

British Columbia to Manitoba in cool spring-fed ponds and pools.

Minute aquatic plants float in the water in dense tangled mats lacking true stem, leaf tissue and root. Several plants may remain attached to each other.

Leaf-like structure on flat thallus (frond), oblong to oblong-lanceolate, $0.6-1 \mathrm{~cm}$.

Plants reproduce by budding, producing new fronds at the edge of the parent.

By minute bulblets that form in the fronds in the fall and sink to the pond bottom. Rise in the spring as the water warms and sunlight penetrates the depths. 
2. little or small duckweed Lemna minor L.

Range: British Columbia to Manitoba in standing water.

Plant: $\quad$ Common in quiet water and in among cattails and other emergent vegetation; forms bright green mats or carpets.

Leaves: $\quad$ Fronds round, 2-5 $\mathrm{mm}$ in diameter, thick, bright green, small rootlike structures hang from underside of fronds.

Reproduction: Forms rosettes of small fronds that separate slowly to produce new plants.

3. larger duckweed, water flaxseed Spirodela polyrhiza (L.) Schleid.

Range:

British Columbia to Manitoba along stream margins and in pools and ponds.

Plant: $\quad$ Has several root-like structures hanging down from broad 3-8 mm plant.

Leaves: $\quad$ Fronds round to obovate, thick, dark green above with reddish to purple underside, 5-11 nerved with 6-18 root-like structures.

Reproduction: Plants reproduce by budding, producing new fronds at the edge of the parent.

Overwintering: From minute bulblets formed in the fall that sink to the bottom sediments to overwinter. Rise to surface when the water warms in the spring. 
Group IV. Emergent aquatic plants

A. Plants with rather stiff, upright, or upshooted leafless stems, or with long narrow leaves coming from lower parts of stems, growing in clumps or patches on the canal or lake bottom and coming up year after year from rootstocks or creeping rhizomes. Flowers usually individually inconspicuous in greenish, yellowish, or brown clusters.

1. softstem bulrush Scirpus validus Vahl.

Range: $\quad$ British Columbia to Manitoba, very common and widespread.

Plant: $\quad$ Tufted or stoloniferous perennial on wet soil, usually growing in up to $1 \mathrm{~m}$ of water. Stems thick $(0.8-2.5 \mathrm{~cm})$ at base, light green, soft and spongy.

Leaves: $\quad$ True leaves lacking, culms or stems rounded in cross-section, $0.5-2.5 \mathrm{~m}$ tall.

Flowers: $\quad$ Spikes on compound inflorescence ascending at top and spreading and open at bottom, 1-6 cm long, each bearing several short peduncled spikelets.

Reproduction: Reproduces extensively by stout rhizomes covered with fibrous roots.

2. hardstem bulrush Scirpus acutus Muhl.

Range:

Plant:

Leaves:

Flowers:

Reproduction: From thick, spongy rhizomes with swollen roots.
British Columbia to Manitoba, widespread in hard water areas.

Perennial growing on wet soil. Stems or culms 3-10 $\mathrm{mm}$ thick at base, dark olive green, firm in texture growing to $0.5-3.0 \mathrm{~m}$. Stems hard to crush.

True leaves lacking, stems or culms rounded in cross section.

Spikes as compound inflorescence, rather stiffly ascending and divergent, $1-8 \mathrm{~cm}$ long, each bearing 1-5 spikelets. 
3. wire rush, baltic rush Juncus balticus willd.

Range: $\quad$ British Columbia to Manitoba in salt or brackish water on sandy shores.

Plant: $\quad$ Smooth perennial herb looking like grasses or sedges, 20-80 cm tall, leaves arising at intervals along creeping rootstock.

Leaves:

Stems of culms in small tufts or singly channelled, more or less rounded with basal leaves reduced to loose brownish sheaths.

Flowers: Inflorescence is loosely forked and diffusely branched, 2-4 cm long, purplish brown in color.

Reproduction: Plants appear as rows arising from underground rootstock.

4. soft rush Juncus effusus $L$.

Range: $\quad$ British Columbia to Manitoba with plants highly variable in response to regional temperatures and water conditions.

Plant: Has stems or culms borne in large clumps, generally firm, $0.4-2 \mathrm{~m}$ tall. Very fine ridges or furrows along green stem.

Leaves: Generally lacking.

Flowers: Inflorescence many-flowered, forking and densely compact, greenish to brown in color.

Reproduction: Plants appears as clumps, densely packed on stout underground rhizome.

5. needle rush, slender spikerush Eleocharis acicularis R. \& S.

Range: $\quad$ British Columbia to Manitoba in shallow, 10-12 cm clear fresh water.

Plant: In tufted carpets from underground, fine rhizomes and stolons. Grows beneath water but can stand short periods of exposure to air.

Leaves: $\quad$ Culms or stems very fine, angular and furrowed, ranging from 2-10 cm long. 
Flowers: $\quad$ Spikelets flattened, linear, and narrowly rounded, 2-7 mm long. Flowers 3-15, very fine and delicate, yellow turning reddish brown at maturity.

Reproduction: Extensive from stolons.

Uses: $\quad$ Plant has been looked at as potential carpeting or seeded grass-like vegetation for canals and ornamental water gardens.

6. broad-leaf cattail Typha latifolia L.

Range:

British Columbia to Manitoba appearing in almost any wet place and usually first invader in newly excavated ditches and dugouts.

Plant: $\quad$ Marsh or aquatic herb with coarse creeping rootstock spreading extensively. Stems stout, 1-2 m tall.

Leaves: Leaves linear, 6-25 $\mathrm{mm}$ broad and extending beyond stem, pale green to grayish-green in color.

Flowers: Long, mace-like, very dense cylindrical spike terminating at end of stem. Top part the male flowers, yellow in color from pollen; lower portion has female flowers, green turning brown at maturity.

Reproduction: Underground stems are so extensive that a patch of cattails an acre in extent may only be three to four plants.

7. narrow-leaf cattail Typha augustifolia L.

Range: $\quad$ Manitoba, chiefly in strongly basic or alkaline water. Plants have not been seen west of Manitoba.

P1ant: Looks like typical cattail, but leaves are much narrower.

Leaves: $\quad$ Few (less than 10), convex on the back, green, 3-8 $\mathrm{mm}$ wide.

Flowers: In long, narrow, dense cylindrical spike at end of stem. Top part male flowers separated by short interval. Lower portion female flowers, reddish brown. 
8. big bur reed Sparganium eurycarpum Engelm.

Range :

Plant:

Leaves:

Flowers:

Reproduction: Extensively from underground rootstock or rhizome.
British Columbia to Manitoba along mucky lake shores.

Marsh or aquatic perennial plants arising from underground rootstocks. Stems stout, erect, $50-150 \mathrm{~cm}$ tall.

Stiffish, flat with a slight keel or ridge, 6-12 mm broad. Longitudinal and cross veins very evident in leaves give a mesh-like pattern.

Unisexual, form dense, hard spherical heads or small balls.

9. floating-leaf bur reed Sparganium fluctuans (Morong) Robinson

Range:

Plant:

Leaves:

Flowers:
British Columbia to Manitoba in deep or shallow water in isolated pockets.

Slender aquatic with stems and leaves floating, up to $1.2 \mathrm{~m}$ long.

Very elongated 1.5-5 mm broad, convex with the underside of the leaf appearing mesh-like and the top side opaque.

Male heads 1-6, close together on upper part of inflorescence, female flowers on lower portion, 1-2 cm in diameter when mature.

B. Plants with upright or upshooted stems with grasslike leaves on two sides (one plane). Most reproduce by creeping rhizomes or rootstocks but a few new plants grow each year from seed.

1. reed phragmites Phragmites communis Trin.

Range:

British Columbia to Manitoba along fresh and alkaline marshes, pond margins and irrigation and drainage canals.

Plant:

Very large perennial up to $4 \mathrm{~m}$ tall with long, creeping rhizome. Stems generally 1.5-3 m tall, stout. 
Leaves:

Leaf blade flat, 1-6 cm wide, smooth, 15-60 cm long; leaf sheaths overlap.

Flowers: $\quad$ Inflorescence $10-40 \mathrm{~cm}$ long, dense with branches ascending to nodding, tawny to purplish color flowers; long silky hairs on spikelet give a silky appearance to flowerhead.

2. wild rice Zizania aquatica $L$.

Range: $\quad$ Not native to British Columbia and Alberta but introduced as water fowl food. Native to Saskatchewan and Manitoba.

Plant: $\quad$ Tall aquatic annual grasses with 1-2 m stems.

Leaves: $\quad$ Leaf blade flat, 4-15 mm wide with long sheaths.

Flowers: Inflorescence is large, erect panicle (compound and branched flower cluster) $30-60 \mathrm{~cm}$ long. Lower branches ascending bearing male flowers. Upper branches erect bearing female flowers.

Seeds: Used extensively for food by water fowl and humans.

3. wild millet, barnyard grass Echinochloa pungens (Poir.) Rydb.

Range:

Native plant of stream banks and flats in southeastern Alberta and southwestern Saskatchewan. Spread into cultivated fields and along roadsides.

Plant: $\quad$ Coarse annual grass with thick stems (culms), simple or branching at base, erect from 30-80 cm tall.

Leaves: $\quad$ Leaves long, 5-15 mm broad, smooth with compressed sheaths.

Flowers: Inflorescence is stout, open panicle of racemes dark purple to greenish with lower branches spreading with bristles in axis of inflorescence.

Introduction: Japanese millet, E. crusgalli var. frumentacea (Roxb.) Wight, was introduced as forage grass and used as chicken feed. Escaped to roadside ditches and abandoned fields. 
4. reed canary grass Phalaris arundinacea $L$.

Range:

Plant:

Leaves:

Flowers:

Introduction: Once used as forage grass along irrigation canals but too aggressive. Now a serious problem.

5. slough grass Bechmannia syzigachne (Steud.) Fernald

Range:

Plant:

Leaves:

Flowers:

Use:

British Columbia to. Manitoba along shorelines, in swales and sloughs, and in irrigation and drainage ditches.

Robust perennial with creeping rhizomes. Stems (culms) smooth without hairs, 60-150 cm tall.

Leaf blade $10-30 \mathrm{~cm}$ long, 6-15 mm wide.

Dense, of spike-like panicles (or branched flower cluster) with spikelets, 5-6 mm long in club-like masses, pale purple in color.

British Columbia to Manitoba in marshes and along irrigation and drainage ditches.

Coarse annual grass growing on low, wet ground, stems stout, $30-100 \mathrm{~cm}$ tall, light green in color, solitary or tufted.

Leaf blades $10-25 \mathrm{~cm}$ long and $5-8 \mathrm{~mm}$ broad, rough to touch.

Inflorescence narrow, crowded in interrupted flower head composed of numerous ascending one-sided spikes.

Seeded to stabilize prairie sloughs.

C. Plants with upright stems with grasslike leaves on three sides. Stems usually stand close to each other in colonies with leaves interlocked. Flowers occur between scales, which usually overlap in several rows to form spikelets. Most reproduce year after year from rootstocks.

1. beaked sedge Carex rostrata Stokes

Range: British Columbia to Manitoba along wet shores in shallow water and in swamps. 
Plant: Culms or triangular stems thickened and spongy at base. Plants 50-100 cm tall, perennial herbs.

Leaves:

Three-ranked, long and narrow, 2-10 mm, pale green with closed sheaths. Prominent cross markings between veins.

Flowers: Monoecious with 2-4 staminate spikes on short stalks, upper part of stem. Pistillate flowers on lower stem, cylindrical, dense, with nuttel encased in beaked sac.

Rhizome: Horizontal rhizomes and stolons, smooth and angled, give rise to a number of upright stems.

Value: $\quad$ Seeds important to wildlife, plants grazed by cattle.

D. Plants with upright, sprawling, or horizontal stems with singly placed, non-grasslike, lance-shaped, untoothed leaves. Flowers clustered at the end of stems.

1. water smartweed Polygonum amphibium var. stipulaceum (Coleman) Fernald

Range: $\quad$ British Columbia to Manitoba in wooded swamps and along shores of streams, ditches, irrigation canals and range dugouts.

Plant:

Perennial with slender, tough, running rootstocks, generally aquatic but variable in habitat and leaf characters. May grow on exposed mud flats as water recedes.

Leaves: Large, oblong to elliptic with long petioles floating on surface of water. Underwater stems trail.

Flowers: $\quad$ Spike-like racemes are solitary or in pairs with bright scarlet to pink flowers, $1-3 \mathrm{~cm}$ long, $1.5 \mathrm{~cm}$ wide.

Problem: Plants trail out into water from shoreline, eventually plugging irrigation and drainage ditches. 
2. marsh smartweed Polygonum coccineum Muhl.

Range:

Plant:

Leaves:

Flowers:

Problem:
British Columbia to Manitoba in marshes and sloughs, along irrigation and drainage canals.

Perennial with stout creeping rootstock, generally found in marsh areas. Stems upright, simple, 30$100 \mathrm{~cm} \mathrm{tall.}$

Short-petioled, broadly to narrowly lanceolate, commonly pubescent, with leaf tapering to point.

Racemes 1 or 2, spike-like slenderly cylindrical, 3-12 cm long, scarlet to pink in color.

Plants take over moist areas and then encroach into cultivated fields. 


\section{SELECTED REFERENCES}

The following references are suggested as sources of general identification and taxonomy of aquatic vegetation in North America and Canada.

Arber, A. 1920. Water plants. A study of aquatic angiosperms. Reprinted 1963 by Wheldon and Wesley, Ltd., Codicote, Herts, England, and Hafner Publishing Co., New York, NY.

Burland, G. R. (ed.) 1989. An identification guide to Alberta aquatic plants. Alta. Environment, Pesticide Management Branch, Edmonton, Alberta.

Cowardin, L. M., Golet, F. C., and LaRoe, E. T. 1979. Classification of wetlands and deepwater habitats of the United States. Office of Biological Services, Fish and Wildlife Service, U.S. Dept. Interior, Washington, DC.

Fassett, N. C. 1966. A manual of aquatic plants. The University of Wisconsin Press, Madison, WI.

Fernald, M. L. 1950. Gray's manual of botany. American Book Company, New York, NY.

Moss, E. H. 1959. Flora of Alberta. University of Toronto Press, Toronto, Ontario.

Muenscher, W. C. 1944. Aquatic plants of the United States. Comstock Publishing Co., Inc., Cornell University, Ithaca, NY.

Sculthorpe, C. D. 1967. The biology of aquatic vascular plants. Edward Arnold (Publishers) Ltd., London, England.

Tarver, D. P., Rodgers, J. A., Mahler, M. J., and Lazor, R. L. 1979. Aquatic and wetland plants of Florida. Bureau of Aquatic Plant Research and Control, Dept. of Natural Resources, Tallahassee, FL.

Welch, P. S. 1952. Limnology. McGraw-Hill Book Co., Inc., New York, NY. Wetzel, R. G. 1975. Limnology. W. B. Saunders Co., Toronto, Ontario.

Winterringer, G. S., and Lopinot, A. C. 1966. Aquatic plants of Illinois. Dept. of Registration and Education, I1l. State Museum Div. and Dept. of Conservation, Div. of Fisheries, State of Illinois, Chicago, IL. 
Recycled 17 Papier

Paper $\square S$ recyclé 


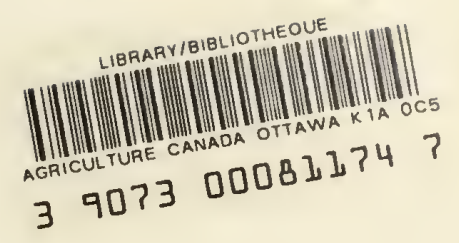


